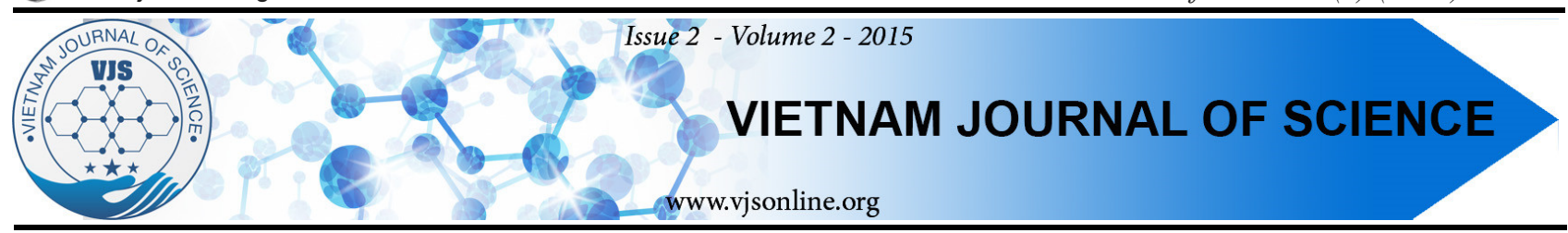

RESEARCH \& REVIEW

\title{
Oncolytic Virus - an Effective Targeting Therapy for Cancer Treatment
}

\author{
Khue Gia Nguyen ${ }^{1,2}$, Dang Quan Nguyen $^{3}$, and Le Xuan Truong Nguyen ${ }^{4 *}$ \\ ${ }^{1}$ Laboratory of Vaccine and Immunotherapy Delivery, University of Arkansas at Fayetteville, AR 72701, USA \\ ${ }^{2}$ Laboratory of Stem cell Research and Application, University of Science, Ho Chi Minh City, Vietnam \\ ${ }^{3}$ Department of Medical Biotechnology, Biotechnology Center of Ho Chi Minh City, Ho Chi Minh City, Vietnam \\ ${ }^{4}$ Stanford Cancer Institute, Stanford University School of Medicine, Stanford, CA 94305, USA
}

\section{ARTICLE INFO}

Editor:

Mai Tran Ph.D., International University, Ho Chi Minh city National University

Corresponding author:

Khue Gia Nguyen

kgnguyen@email.uark.edu

Keywords:

oncolytic virus

cancer therapy

\section{ABSTRACT}

The oncolytic viruses that were discovered in the late of 19th century have been recently considered as an effective anti-cancer therapy due to its selective replication activity in cancer cells. Currently, at least nine types of virus have been studied in clinical trials for treating a variety of cancers including T-VEC and Reolysin. In this review, we focus on historical researches of oncolytic viruses. We also describe the molecular mechanism of oncolytic viruses in cancer cells. Positive clinical trial results strongly suggest oncolytic viruses as an effective targeting virotherapy for treating cancer. 


\section{BRIEF OVERVIEW OF ONCOLYTIC VIRUSES}

Viruses are usually considered as infectious agents that can lyse cells and cause deadly diseases such as Acquired Immune Deficiency Syndrome (HIV/AIDS), Severe Acute Respiratory Syndrome (SARS), or Ebola Hemorrhagic Fever (EHF). Indeed, viruses are dangerous causative agents because of its wide range of targeting cell types and rapid infectious rate. According to the estimation of World Health Organization (WHO), 35.3 million people around the world had HIV infection in 2012 and this number is increasing every year with $0.8 \%$ global prevalence [1]. An outbreak epidemic of Ebola, which began in February 2014 at Guinea, caused suspectedly 1,323 cases with 729 deaths that have been reported as of 27 July 2014 [2]. Measles virus recently reemerged in Vietnam with spreading out in 24 cities and caused approximately 1000 infectious cases [3]. Despite of the virus' effects on human diseases, a large amount of studies demonstrate that viruses can be modified by
Generally, this concept describes several specific viruses that lyse cancer cells, but leave healthy cells unharmed.

Historically, anti-cancer activity of virus was recorded in the late of $19^{\text {th }}$ century on cancer patients infected with virus. In 1896, a myelogenous leukemia patient had significant dropping of leukocyte count after getting influenza infection [7]. In another case, a lymphatic leukemia boy was infected with chickenpox virus, which led to cancer regression when his spleen size and leukocyte number returned to normal. These observations suggested that viral infection could treat cancer in patients. Moreover, compromised immune system on cancer patients could facilitate the anti-cancer activity of virus. Indeed, clinical experiments of virotherapy on cancer patients became popular in the middle $20^{\text {th }}$ century [7]. These studies were often conducted in cancer patients with live virus that directly were extracted from virus-infected patients without any attenuating treatment. Although these experiments

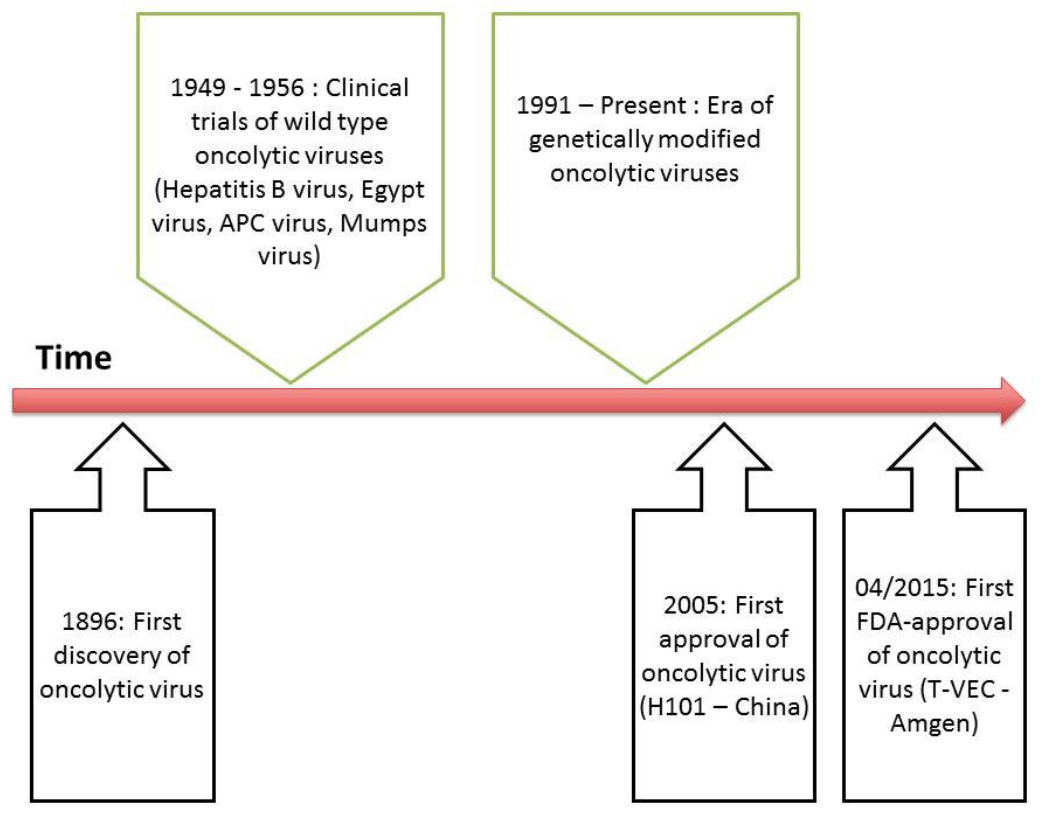

Figure 1: A timeline of milestones in the development of oncolytic virus as a cancer therapy. Since the first discovery in the late $19^{\text {th }}$ century, oncolytic viruses have been getting more attention to be used as anti-tumor therapy. Until the middle of $20^{\text {th }}$ century, clinical trials of oncolytic viruses on cancer patients, who were transmitted body fluids containing viruses, revealed the potential of using wild type viruses for treating cancer. Even though these wild type viruses can inhibit tumor growth in some immunosuppressed patients, they are easily recognized and cleared by immune system. Also, these wild type viruses can cause infection to normal cells leading to fatality in patients. Thus, modern approaches of genetics in recent years, which enhance selective viral replication on tumor cells, gene-carrying ability, and penetration of host immune defenses, allow oncolytic viruses to improve their antitumor ability.

genetic engineering and used as an effective therapy in treating cancer in both preclinical models and clinical trials with human patients [4] [5] [6]. These viruses are called oncolytic viruses (OVs) in which "onco" and "lytic" represent for "cancer" and "lysis", respectively. achieved positive results with tumor regressions in cancer patients, the oncolytic efficacy was still limited due to (1) virus activity was also suppressed by the immune system; (2) the contamination of virus infection in normal cells; and (3) the virus' effects causing fatality in patients [4]. 
There were four main clinical studies in this era using viruses as a therapy for cancer treatment including Hepatitis B virus [8], Egypt 101 virus [9], Adenovirus adenoidal pharyngeal-conjuctival virus (APC) [10], and Mumps virus [11]. In 1949, Hepatitis B virus was first used for treating Hodgkin's disease in 21 patients [8]. The patients were administrated by parenteral injection of impure human serum containing virus. In the results, 13/22 patients had hepatitis, 7 of whom had partial tumor responses to therapy and 4 among them had tumor size reduction [8]. Three years later, Southam et al. used Egypt 101 virus to treat advanced - unresponsive neoplastic disease in 34 patients by using intravenous and intramuscular injection of bacteria-free mouse and human tissue extracts containing viruses. The results showed that 27/34 patients were successfully infected by Egypt 101 virus; 14/34 patients were positive with oncotropism, which defines the ability or property of virus to find and destroy malignant tumor cells, but ignore the healthy cells; and 4/34 temporarily had tumor regression [9]. In 1956, APC virus was employed by Georgiades et al. to apply in 30 cervical carcinoma patients. They obtained positive results with 26/30 inoculations in localized necrosis when injected APC to patients through intraarterial, intravenous administration [10]. In another study, Asada conducted clinical trials to treat terminal gastric, pulmonary, uterine cancers by using wild type mumps virus in 90 cancer patients. There were 37/90 complete regression patients, 42/90 growth suppression patients and 11/90 unresponsive patients [11].

In 1991, modern approach for applying OVs in treating cancer was officially begun by a research on modified HSV genome with deletion of thymidine kinase (TK) gene [12]. This research showed that virulence of this virus strain was reduced in normal neurons, but selective in human glioma cells. In detail, TK-negative mutant of herpes simplex viruses -1 could lyse 5 glioma cell lines (U87 cell line, T98G cell line, and 3 other cell lines obtained from human glioma patients). In immune deficiency mice, these viruses could inhibit tumor growth from injected subcutaneous U87 glioma cells and prolong mice survival [12] [4]. After this study, the research on OVs has been more focused on the interaction of virus protein and dysfunctional protein inside cancer cells. Among them, Onyx-15 was an engineered genome oncolytic adenovirus that carried viral genome with deletion of E1B55kD gene [13] [4] [14] . It has been shown that Onyx-15 could replicate selectively and lyse p53-deficient tumor cells and ignore healthy cells [13]. Bischoff $e t$ al. proved the efficacy of this virus strain by injecting them into nude mice that carried p53-deficient human cervical carcinomas. The results showed that Onyx-15 caused a significant reduction in tumor size and decreased 60 percent of the tumors in comparison to control group [13]. Unexpectedly, the clinical trials indicated that Onyx-15 was ineffectively replicated in certain tumor cells [12]. Therefore, the exact replication mechanism in this virus is still a controversial topic [13] [14]. Due to this unknown, research on this virus has been abandoned in early 2000s in Europe. However, after clinical trial research in China, a similar mutant virus strain with Onyx-15 named as Oncorine - H101 was approved by Chinese State Food and Drug Administration to treat late-stage of nasopharyngeal cancer in combination with chemotherapy [15].

Currently, there are at least 9 types of virus family being studied on clinical trials at various phases (Table 1) [16]. Talimogene laherparepvec (T-VEC) and Reolysin, phase III of clinical trial of which were completed, are the two of the promising OVs. T-VEC is an oncolytic herpes simplex virus currently being studied for the treatment of melanoma and other advanced cancers. This virus was initially developed by BioVex, Inc. under the name OncoVEX $^{\text {GM-CSF }}$ until it was acquired by Amgen in 2011. With the announcement of positive results in March 2013, T-VEC was the first oncolytic herpes simplex virus to be proven effective in a phase III clinical trial for treating melanoma [17] [18]. Recently, T-VEC was voted as the first oncolytic virus to gain FDA (US Food and Drug Administration) - approval recommendation for treating melanoma in April, 2015 [19]. This recommendation may lead to a great opportunity for $\mathrm{T}$ VEC to become the first oncolytic virus approved by FDA for widely using on cancer patients. Reolysin, which is originated from respiratory enteric orphan virus, was developed by Oncolytic Biotech Company for the treatment of various cancers and cell proliferative disorders. Phase III clinical trial of this virus was completed for treating carcinoma, squamous cell of the head and neck cancer in combination with paclitaxel and carboplatin [20].

\section{THE ONCOLYTIC MECHANISM OF OVs}

One of the most important ability of OVs to attack cancer but not healthy cells is the selective replication ability. The selective replication of OVs could be achieved by taking advantage in several key-signaling pathways in cancer cells, including p53, interferon response pathway, epidermal growth factor receptor (EGFR) and Ras pathway, interferon-induced and doublestranded RNA-dependent protein kinase (PKR) pathways. Interestingly, these signaling pathways in cancer and normal cells are differently regulated by OVs [16] [4] [14]. 

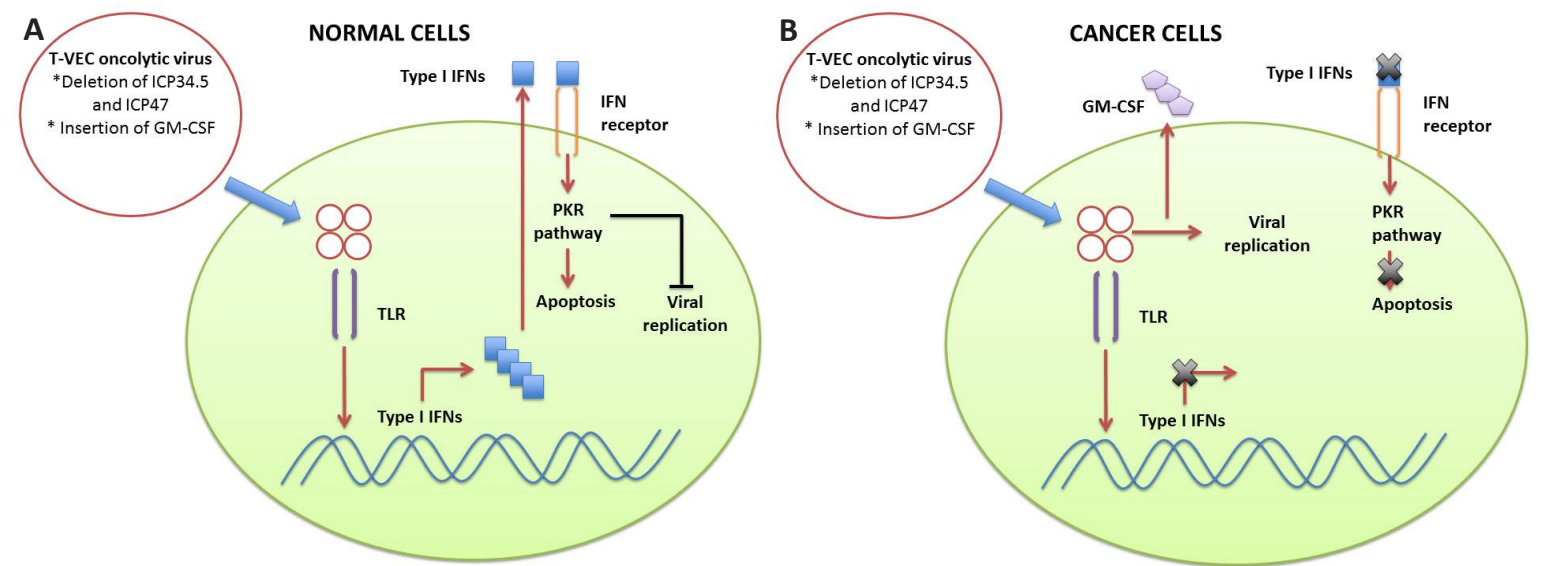

Figure 2. A (left). Illustration of oncolytic virus (T-VEC) activity in normal cells. Deletion of ICP34.5 gene leads to virus recognizing by viral defense system in normal cells, which includes type I IFN and double-stranded RNAdependent protein kinase signaling. This system activates a signaling cascade that prevents viral replication and directs infected cells for apoptosis or necrosis. ICP34.5: Infected cell protein 34.5, ICP47: Infected cell protein 47, GM-CSF: Granulocyte macrophage colony-stimulating factor, TLR: Toll-like receptor, IFNs: Interferons, PKR: double-stranded RNA-dependent protein kinase. Figure 2. B (right). Illustration of oncolytic virus (T-VEC) activity in cancer cells. Due to the dysfunction of PKR pathway, cancer cells cannot target and inhibit viral replication. Deletion of ICP47 gene leads to antigen presented to cell surface, which in turn recruits immune cells to tumor site. Expression of GM-CSF, which is inserted to viral genome, also enhances anti-tumor immune response by recruiting and stimulating dendritic cells to tumor sites. ICP34.5: Infected cell protein 34.5, ICP47: Infected cell protein 47, GM-CSF: Granulocyte macrophage colony-stimulating factor, TLR: Toll-like receptor, IFNs: Interferons, PKR: double-stranded RNA-dependent protein kinase.

\section{P53}

P53 is a key tumor suppressor protein that can arrest cell cycle or induce cell apoptosis in cells under stress conditions. Moreover, the tumor suppressor protein p53 is a main protein in cellular defense system against viruses [14]. Due to gene mutations or the influence of p53 inhibitors, p53 expression is reduced in a variety of cancer cells [21] [22]. The suppression of p53 enhances cancer cells' susceptibility to oncolytic viruses and facilitates viral replication inside cancer cells. In contrast, the normal expression of p53 in healthy cells inhibits both the infection and replication of oncolytic viruses [14]. This principle was employed in Onyx-15 and H101 oncolytic viruses as mentioned in the first part of this review [15].

\section{Interferon response and Ras pathway}

Another strategy to gain selective replication in cancer cells by oncolytic virus is to interfere with interferon response and EGFR/Ras pathway [23]. In normal cells, interferon $\alpha$ or $\beta$ inhibits the viral replication inside the cells by blocking translation of viral RNA into protein. In order to replicate, vaccinia virus, which is the causative agent of eradicated smallpox disease, employs protein B18R to inhibit the interferon pathway. Thus, in cancer cells, selective replication will be achieved when B18R encoding gene is removed from vaccinia virus to reduce the expression of interferon $\alpha$ or $\beta$ receptor [23]. The EGFR/Ras pathway is usually dysregulated in cancer cells, leading to a significant increase in nucleotides, which is a very favorable condition for Vaccinia virus replication. Thymidine kinase (TK) and Vaccinia grow factor (VGF) are viral proteins that have similar functions with the EGFR/Ras pathway in making nucleotide pool for viral replication. Therefore, TK and VGF encoding genes could be removed from vaccinia viral genome in order to achieve selective replication [23]. The engineered vaccinia viruses could not replicate in normal cells due to lack of their vital proteins whereas they could selectively replicate in cancer cells that do favor virus replication by abnormal expression of EGFR/Ras pathway and IFN response pathway. In addition, key immune system genes can be inserted into virus genome, such as GM-CSF to further enhance recognition of cancer antigens by immune system and promote the oncolytic effect. 


\section{Interferon (IFN) and double-stranded RNA-} dependent protein kinase (PKR) pathways

Talimogene laherparepvec (T-VEC), which was developed from herpes simplex virus 1 (HSV-1), selectively replicate in cancer cells by taking advantage of the type I IFN and double-stranded RNA-dependent protein kinase (PKR) pathways. When healthy cells are infected by viruses, PKR pathway inhibits viral protein synthesis by phosphorylation of eiF2 $\alpha$. In order to prevent this inhibition, herpes simplex virus expresses ICP34.5 protein to dephosphorylate eiF2 $\alpha$ and trigger viral protein synthesis. In addition, interferon type 1 (IFN $\alpha$ or IFN $\beta$ ) expressed by infected cells could produce an activation signal on PKR by binding to interferon type 1 receptors because one of their downstream targets is PKR [14]. However, cancer cells which possess the dysregulation of this pathway will favor the replication of oncolytic virus [14] [24]. Deletion of ICP34.5 in T-VEC genome facilitates selective replication of this virus inside cancer cells. Moreover, there are genetic changes in $\mathrm{T}$ VEC genome that also favor its oncolytic ability. First of all, ICP 47 protein is a viral protein that inhibits virus antigen presenting in target cells by retaining the $\mathrm{MHC}$ class I molecule in the endoplasmic reticulum. This protein-encoding gene is deleted in T-VEC genome, leading to the virus antigen present in virally infected cancer cells. This event recruits immune cells to tumor sites and induces the immune responses. In addition, the insertion of GM-CSF gene into T-VEC genome enhances anti-tumor immune responses. GM-CSF is a cytokine that could recruit and stimulate antigen-presenting cells to tumor sites, thus increases cancer killing ability of virus in combination with that of the immune system [24].

\section{Conclusion}

These examples of oncolytic viruses reveal that antitumor ability of virus can be used as a target therapy for treating cancer. Selective replication and gene carrying ability can be considered as the most important benefits of this method to make oncolytic virus become an effective targeting therapy. Although further research need to be explored to improve the effects of OVs, current positive clinical trial results demonstrate the feasibility of this method in treating cancer.

Table 1. Examples of oncolytic viruses in current clinical trials from nine virus families [16]

\begin{tabular}{|l|l|l|l|}
\hline Virus family & Virus name & Current clinical trial phase & Genetic modifications \\
\hline Herpesviridae & T-VEC & $\begin{array}{l}\text { Completed phase III for treating } \\
\text { melanoma }\end{array}$ & $\begin{array}{l}\text { Deletion of ICP 34.5 and ICP 47 gene } \\
\text { Addition of GM-CSF gene }\end{array}$ \\
\hline Reoviridae & Reolysin & $\begin{array}{l}\text { Completed phase III for treating } \\
\text { head and neck cancers in } \\
\text { combination with paclitaxel and } \\
\text { carboplatin }\end{array}$ & None \\
\hline Adenoviridae & $\begin{array}{l}\text { Oncorine } \\
\text { (H101) }\end{array}$ & $\begin{array}{l}\text { Approved for treating head and } \\
\text { neck cancer with Cisplatin in } \\
\text { China }\end{array}$ & Deletion of E1B55KD gene \\
\hline Poxviridae & JX-594 & $\begin{array}{l}\text { Ongoing phase IIB for treating } \\
\text { hepatocellular carcinoma }\end{array}$ & $\begin{array}{l}\text { Deletion of Thymidine Kinase gene } \\
\text { Addition of GM-CSF gene }\end{array}$ \\
\hline Paroviridae & ParvOryx & $\begin{array}{l}\text { Ongoing phase I and II for treating } \\
\text { Glioma }\end{array}$ & None \\
\hline Paramyxoviridae & MV-NIS & $\begin{array}{l}\text { Ongoing phase I for treating } \\
\text { Myeloma in combination with } \\
\text { Cyclophosphamide }\end{array}$ & $\begin{array}{l}\text { Gene modifications for not blocking } \\
\text { STAT1 and MDA5 pathway }\end{array}$ \\
\hline Picornaviridae & PVS-RIPO & $\begin{array}{l}\text { Ongoing phase I for treating } \\
\text { Glioma }\end{array}$ & $\begin{array}{l}\text { Controlled translation by the internal } \\
\text { ribosome }\end{array}$ \\
\hline Rhabdoviridae & VSV-hIFN $\beta$ & $\begin{array}{l}\text { Ongoing phase I for treating } \\
\text { hepatocellular carcinoma }\end{array}$ & $\begin{array}{l}\text { Addition of human IFN } \beta \text { gene } \\
\text { Glioma poing phase I and II for treating }\end{array}$ \\
\hline
\end{tabular}

GM-CSF, granulocyte-macrophage colony-stimulating factor; hIFN $\beta$, human interferon- $\beta$; ICP, infected cell protein; MDA5, melanoma differentiation-associated protein 5; MV, measles virus; NIS, sodium-iodide symporter; PVS, poliovirus Sabin; $\mathrm{RB}$, retinoblastoma protein; RIPO, Rhinovirus-poliovirus hybrid; STAT1, signal transducer and activator of transcription 1; US, unique sequence: VSV, vesicular stomatitis virus. 


\section{ACKNOWLEDGEMENT}

This work was supported in part by a research of science and technology research grant from Department of Science and Technology of Ho Chi Minh City, Vietnam to LXTN (226/2013/HD-SKHCN).

\section{ABOUT THE AUTHORS}

Khue Nguyen is a Ph.D. student in Cell and Molecular Biology at the University of Arkansas, USA. Currently, he is working in the research group at the Laboratory Vaccines and Immunotherapy Delivery. His main research focuses on using glycosaminoglycan molecules for enhancing the activity of immune system. Dr. Dang-Quan Nguyen graduated with a Ph.D degree in Immunology from the University of Justus Liebig, Germany. He is currently the Director of Division of Medical Biotechnology at Biotechnology Center of Ho Chi Minh City. Dr. Truong Nguyen is working in Biotechnology Center of Ho Chi Minh City as a scientific expert.

Khuê hiện là nghiên cứu sinh theo chuyên ngành Sinh học Phân tử và Tế bào tại Đại học Arkansas, Hoa Kỳ. Hiện tại, anh đang tham gia vào nhóm nghiên cứu tại phòng thí nghiệm phân phối vaccine và liệu pháp miễn dịch. Hướng nghiên cứu chính của anh là sử dụng các phân tử glycosaminoglycan trong việc thúc đẩy hoạt động của hệ miễn dịch. Tiến sĩ Nguyễn Đăng Quân tốt nghiệp chuyên ngành miễn dịch học tại đại học Justus Liebig, Đức. Anh hiện là trưởng phòng Công nghệ Y sinh tại TT CNSH TPHCM. Tiến sĩ Nguyễn Lê Xuân Trường hiện là chuyên gia khoa học công tác tại TT CNSH TPHCM.

\section{REFERENCES}

1. WHO, HIV/AIDS, in Global Health Observatory, b.W.r. Adult HIV prevalence (15-49 years), Editor. 2013.

2. WHO. Ebola virus disease, West Africa - update 29 July 2014. WHO: Outbreak news. 29 July 2014. 2014.

3. Nguyen, C. Measles Reemerges in Vietnam. The Disease Daily 2014; Available from:

http://healthmap.org/site/diseasedaily/article/measles-eemergesvietnam-22814.

4. Russell, S.J., K.W. Peng, and J.C. Bell, Oncolytic virotherapy. Nat Biotechnol, 2012. 30(7): p. 658-70.

5. Guo, Z.S., S.H. Thorne, and D.L. Bartlett, Oncolytic virotherapy: molecular targets in tumor-selective replication and carrier cellmediated delivery of oncolytic viruses. Biochim Biophys Acta, 2008. 1785(2): p. 217-31.

6. Cerullo, V., et al., Chapter eight--Oncolytic adenoviruses for cancer immunotherapy: data from mice, hamsters, and humans. Adv Cancer Res, 2012. 115: p. 265-318.

7. Kelly, E. and S.J. Russell, History of oncolytic viruses: genesis to genetic engineering. Mol Ther, 2007. 15(4): p. 651-9.

8. Hoster, H.A., R.P. Zanes, Jr., and E. Von Haam, Studies in Hodgkin's syndrome; the association of viral hepatitis and Hodgkin's disease; a preliminary report. Cancer Res, 1949. 9(8): p. 473-80.

9. Southam, C.M. and A.E. Moore, Clinical studies of viruses as antineoplastic agents with particular reference to Egypt 101 virus. Cancer, 1952. 5(5): p. 1025-34.

10. Georgiades, J., et al., Research on the oncolytic effect of $A P C$ viruses in cancer of the cervix uteri; preliminary report. Biul Inst Med Morsk Gdansk, 1959. 10: p. 49-57.

11. Asada, T., Treatment of human cancer with mumps virus. Cancer, 1974. 34(6): p. 1907-28.

12. Martuza, R.L., et al., Experimental therapy of human glioma by means of a genetically engineered virus mutant. Science, 1991. 252(5007): p. 854-6.

13. Bischoff, J.R., et al., An adenovirus mutant that replicates selectively in p53-deficient human tumor cells. Science, 1996. 274(5286): p. 373-6.
14. Chiocca, E.A., Oncolytic viruses. Nat Rev Cancer, 2002. 2(12): p. 938-50.

15. Liu, T.C. and D. Kirn, Gene therapy progress and prospects cancer: oncolytic viruses. Gene Ther, 2008. 15(12): p. 877-84.

16. Miest, T.S. and R. Cattaneo, New viruses for cancer therapy: meeting clinical needs. Nat Rev Microbiol, 2014. 12(1): p. 23-34.

17. Deal watch: Amgen buys oncolytic virus company. Nat Rev Drug Discov, 2011. 10(3): p. 166.

18. Schmidt, C., Amgen spikes interest in live virus vaccines for hardto-treat cancers. Nat Biotechnol, 2011. 29(4): p. 295-6.

19. Dolgin, E., Oncolytic viruses get a boost with first FDA-approval recommendation. Nat Rev Drug Discov, 2015. 14(6): p. 369-71.

20. Carew, J.S., et al., Reolysin is a novel reovirus-based agent that induces endoplasmic reticular stress-mediated apoptosis in pancreatic cancer. Cell Death Dis, 2013. 4: p. e728.

21. Hollstein, M., et al., p53 mutations in human cancers. Science, 1991. 253(5015): p. 49-53.

22. Olivier, M., M. Hollstein, and P. Hainaut, TP53 mutations in human cancers: origins, consequences, and clinical use. Cold Spring Harb Perspect Biol, 2010. 2(1): p. a001008.

23. Kirn, D.H. and S.H. Thorne, Targeted and armed oncolytic poxviruses: a novel multi-mechanistic therapeutic class for cancer. Nat Rev Cancer, 2009. 9(1): p. 64-71.

24. Liu, B.L., et al., ICP34.5 deleted herpes simplex virus with enhanced oncolytic, immune stimulating, and antitumourproperties. Gene Ther, 2003. 10(4): p. 292-303. 